\title{
The Ensnaring Oil: an Ecofeminist Critique of Kaine Agary's Yellow Yellow
}

\author{
Olubunmi O. Ashaolu \\ Department of Foreign Languages \\ Obafemi Awolowo University \\ Nigeria
}

\begin{abstract}
The natural environment has been speculated as feminine, likewise, it occupies a significant position in the daily activities of a woman. In essence, her roles in protecting nature in Africa cannot be underestimated. The bond between woman and nature also reveals the extreme connection that links female oppression to the abuse of nature. Hence, their joint interdependence and subjugation call for an ecofeminist inquiry. From the theoretical standpoint of ecofeminism, this paper evaluates Kaine Agary's Yellow-Yellow to advance a critical discourse on the variables of the closeness between the joint exploitation / degradation of African woman and her environment. First, it interrogates how malebiased "power over" and the logic of domination is characterized by environmental degradation. Second, it parodies the persistent oppression of African land, seen in her woman and Mother Earth, to the advantage of the West and African patriarchal capitalists - traitors of African progress. The paper concludes by not only highlighting the complementarity of African woman and nature (Mother - Earth), but also it underpins a symbiotic relationship between woman and the non-human Other.
\end{abstract}

Keywords: degradation, environment, woman, Niger Delta, patriarchal capitalists.

\section{Introduction}

Kaine Agary's Yellow Yellow(2006), winner of ANA/Chevron Prize for environmental writing treats the grim reality of eco-cidal activities of multinational oil companies and their Nigerian accomplices in the Niger-Delta. It portrays how the discovery of the crude oil suggests a curse rather than a blessing to the Niger Delta and Nigerian society. The narration succinctly places greater emphasis on how the foreign and local accomplices subjugate female characters and nature in an overtly and covertly way. Yellow Yellow shows the environmental degradation and its implication on the lives of female characters who suffer doubly as women, allies of and joint preys with nature, under the claws of patriarchal clout. In spite of the overt representation of the double subjugation of African woman and nature in Yellow Yellow, there is little or no attention on the ecofeminist angle of the novel.Ngozi Chuma-Udeh in "The Niger Delta, Environment, Women and the Politics of Survival in KaineAgary'sYellow Yellow" laments "the inner search of a group of people for direction and purpose in their devastated environment" (Udeh111). Herperspective embraces the impact of environmental degradation mainly on people. Sunny Awhefeada in "Degraded Environment and Destabilized Women in Kaine Agary's Yellow Yellow" projects Chuma-Udeh's critique further by showing how Yellow Yellow "mutates between environmental violation and women ruination" (Awhefeada 98). These studies reflect the subjugation of women in a degraded environment. Each of them focuses on the literary representations of the oppressed woman, but neglects the consequences of degraded environment on both nature and woman. While Udeh posits that Yellow Yellow suggests a metaphor of loss of freedom for woman in a degraded environment, Awhefeadalaments the lack of way forward for the Niger Delta woman.

The current critique argues that Agary excessively lays greater emphasis on the entanglement between woman and all aspects of nature/environment, illustrating how the agony of one engenders the misery of the other. As such Yellow Yellowis a very compelling portrait of the interconnections and subjugation of African woman and the environment in a manner that none (woman and environment) can be studied in isolation. The essay examines how the roles of Niger Delta patriarchal capitalists jointly subjugate African women and nature. It shows that Agary forcefully sets her work in the traditional struggles for showcasing the calvary of the voiceless downtrodden- human and non-human, Ijaw woman and Niger Delta ecology. The Ijaw is a major Niger Delta ethnic group (others are the Urhobo, Itsekiri, Ogoni, Izon, Ikwereetc). In Yellow Yellow female protagonists call upon the nature, her co-sufferer, to mitigate the pangs of patriarchal capitalists. 


\section{Ecofeminism.}

Ecofeminism is a political and theoretical movement that addresses gender undercurrents of ecological discourse (Noël Sturgeon 3). Referring to social constructions of diverse ways in which patriarchy violates woman and nature, ecofeminism raises questions on how eco-logical consciousness relates the subjugation of woman to the ruination of nature in her location, leading to the exploitation of both. It calls for an awareness of the inherent gains in the appreciation of humanity and the environment; it also draws out a conscious advantage in the protection of nature and human beings. Multifarious in forms, ecofeminism takes its roots in a wide variety of feminism, it demonstrates that the unjustified types of environmental degradation of nature, ( also known as Mother Earth), are feminist issues as they help one to "understand the plight and status of women cross-culturally" (Warren 4). Women and nature occupy the dual position of the subjugated under patriarchy whether local or global, systemic or individual, such that patriarchal system benefits from the oppression of both. The double subjugation of woman and the environment occurs because they operate a symbiotic relationship such that one depends on the other. Both woman and nature play the same role of procreation in different ways; the biological role of a woman as seen in child bearing just as the land also produces food that nurtures the progeny of the woman.

From another angle, Vandana Shiva in her preface to Ecofeminism(2014) suggests that the violence which the environment undergoes from multinational mineral explorers is resonant and equivalent to the rape of women by men. Ecofeminists show that the subjugation and the link between woman and the non-human Other/the environment (land, rivers, animals, air - henceforth referred to as nature) becomesevident in the exploitation and violence that prevent the physical and self-actualization of the two.

Regional consciousness classifies ecofeminism as occupying two positions (Salman Aneel and Iqbal Nuzhat 854). For instance in the West, it has gained a greater awareness to the point of being a social movement even though it lacks the nuances and global impact of social movement since it has yet to enter the subconscious of the masses of the South. In the non-Western world, ecofeminism is classified more as a philosophy than a movement given that its impact there is still at a budding stage. Whether seen as movement or philosophy, ecofeminism takes root in the campaign against the simultaneous injustice to which the woman and the environment are subjected in the interest of patriarchy and its agents. Noël Sturgeon in Ecofeminist Natures avers that, "Ecofeminism is a movement that makes connections between environmentalism and feminisms; more precisely, it articulates the theory that the ideologies that authorize injustices based on gender, race, and class are related to the ideologies that sanction the exploitation and degradation of the environment" (qtd. in Andrea Campbell vii). Ecofeminism gained momentum in the 1980s struggling for a distinct recognition of sexism within the patriarchal inclined environmental movements. Close to but divergent from "[E]cocriticism... [which]aims to decenter human, often by giving nature 'back' its subjectivity" (Byron CamineroSantangelo 699), ecofeminism expands in scope by its acknowledgement of the theoretical links between woman and ecology.

This theoretical cum gender movement stands out from ecocriticism as it provides a means through which ecocriticism "acknowledge[s] other voices, and created a space in which those voices could begin to address those issues relevant to their lived reality" (Campbell ix-x). Such voices not only reveal the plight of women in a degraded environment, they also sensitize critics and readers to the need for justice forthe woman and the environment. Such justice attained serves the purpose of equity to provide a comely space for woman, humanity and nature.

Nature (emblematized by the female and nonhuman characteristics)i.e. the subjugated occupies a binary opposition in contrast to culture- the dominant (male/human representations) oppressor of nature. Campbell questions the inadequacy of nature/culture dualism as woman is of immense contribution in the realm of culture seen in humanity. Also, the concept of Self /Other, White/Non White does not allow an unbiased interpretation of ecofeminist criticism. It cannot challenge the Western discourse of difference in its own merits as the concept of racial Whiteness tends to shift depending on region and identity - both social and sexual. Rather than see ecofeminism in its essentialist form that tends to promote patriarchy via nature/culture dichotomy, ecofeminists have called for the appreciation of conflations of issues concerning race, class and gender downplaying the essentialism of and promotion of patriarchal constructs. To this end, Campbell shows that "[U]sing a fluid spectrum that describes hierarchies of human, animals, culture and nature rather than dualisms makes ecofeminism encompassing of more than just gender and nature and gives a stronger critique of oppressive ideologies" (ix). In its expansionist steps, ecofeminism not depending solely on essentialism seeks to incorporate all and sundry, calling for political action where necessary. One of its areas of expansion is in literary criticism, both in the North and South, with the proliferation of environmental literature by female writers at the same time as ecofeminist philosophy and criticism grow.

\section{African literature and ecofeminism}


William Slaymaker considers environmental literary/critical writings as the prerogative of the West, describing it as sub-Saharan African "eco-hesitation ... conditioned in part by black African suspicion of the green discourses emanating from metropolitan Western center" (684). But African literary writers are never silent on the environment and its impacts on Africans even before the independence. In Things Fall Apart (1958), Chinua Achebe's depiction of pre-colonial African forest creates a significant and metaphysical awareness of the interdependence between people and nature. It signifies the attention nature has gained in his imaginative literature. Igbo characters e.g. farmers, manifest a deep study and knowledge of weather and climatic conditions to predict and position their planting time. Above all, the Igbo community displays their strong respect for Ani the earth goddess who is responsible for high yielding crops and to whom a week of peace is dedicated between harvest and planting. Through Okonkwo, Achebe depicts the bad implication of breaking the mandatory observance of the week of peace among neighbors before planting. Okonkwo disrespects this custom by beating Ojiugohis wife leading to a strong reprobation by Ezeani, the priest of the earth goddess who chastises Okonkwo:

'We live in peace with our fellows to honour our great goddess of the earth without whose blessings our crops will not grow... The evil you have done can ruin the whole clan. The earth goddess whom you have insulted may refuse to give us her increase and we shall all perish'. His tone now changed from anger to command. You will bring to the shrine of Ani tomorrow one she-goat, one hen, a length of cloth and a hundred cowries' (Achebe 24)

It is significant to note that Okonkwo's indictment places emphasis on the respect for a woman (his wife), without which the community will incur Ani's wrath by losing the land's yield for the year. Maintaining peace with neighbors, especially to one's wife as expected of Okonkwo, underscores the demands of the earth goddess for a peaceful coexistence between man and woman, human and nature. By implication, peaceful living among neighbors signifies the veneration of the goddess and the earth which she stands for, suggesting the Igbo's recognition of the closeness between the community and their ecology. Okonkwo's breaking the rule foregrounds the conflation between the woman (Ani the goddess and Ojiugo- Okonkwo's wife) and her environment which also shows African writers' consciousness of ecofeminism in the colonial era.

Also, literary works as remote as the Negritude writings and their romanticisation of African woman and nature attest to early ecofeminist consciousness. InChants d'ombrea collection of poems, Leopold Sedar Senghor lays bare African ecofeminist awareness of the non-human Other and African woman in the poem "Femme Noire"[Black Woman].

Femme nue, femme noire...

Et voilà qu'aucœur de l'Été et de Midi, je tedécouvre, Terre Promise, du haut d'un haut col calciné

Et ta beauté me foudroieenpleincœur, commel'éclair d'un aigle....

Femme nue, femme noire

Fruit mûr à la chair ferme....

Femme nue, femme noire

Je chante ta beauté qui passe, forme que je fixe dansl'Éternel,

Avant que le Destin jaloux ne tereduiseencendres pour nourrir les raciness de lavie. (Chants d'ombre-Poésieschoisies: 32)

[Nude woman, black woman....

And high on the fiery pass, I find you Earth's promise, in heart of summer and the noon

And your beauty blasts me full-heart like the flash of an eagle in the sun....

Nude woman, black woman

Ripe fruit of firm flesh....

Nude woman, black woman

I sing your passing beauty, your form I fix in the Ageless Night

Before old jealous Destiny brings you down in the fire and gathers your ashes for the suckling life] (My emphasis)

In this poem, black woman's beauty highlights nature as she compares to the flash of an eagle, to juicy fruits; she is the Promise land. The height of her intimacy with land becomes overwhelming when Senghor desperately desires her before she answers the call of nature and she is buried to nourish the earth. While Senghor's ecofeminist ideas do not focus on environmental degradation, it points to the writer's consciousness of the strong link between woman and nature. More than colonial African literature, contemporary writings e.g. Agary's Yellow Yellow, overtly depicts female protagonists' subjugation and their connectivity to environmental devastation.

\section{Agary's ecofeminist engagement in Yellow Yellow.}

Yellow Yellow's political setting, 1996, "the year after the government hanged Ken Saro-Wiwa"1 (34) is significant. 
It underscores one of the key periods of the Nigerian government's corrupt collaboration with multinational oil companies in their destruction of the ecology of Niger Delta and the origin of the public repression of local environmental preservation activists. Yellow Yellow opens in a rural Ijaw setting of a crude oil polluted village. It depicts the lives of the protagonist and narrator Zilayefaa.k.a Yellow Yellow, her mother Binaebi or simply Bibi and other rural women who struggle with complications arising from crude-oil-polluted barren land and waters. In contrast to rural women, affluent and rich women the elderly Madam George a.k.aSisiand her younger assistant Lolo, live in the city of Port Harcourt. They care for downtrodden girls seen in the way they serve as Zilayefa's urbanised surrogate mothers. The village and Port Harcourt present contrastive analysis of abject poverty and affluence which woman, her land and rivers undergo in the novel. The two settings prepare readers to the show of shame and pity to which Niger Delta woman and her environment are subjected.

This novel has two spatial settings: a village which is the den of poverty, hunger, filth, polluted water, and land deep in despoliation and Port Harcourt, the urban setting which displays comfort and wealth enjoyed by male characters White foreigners and Nigerian capitalists who see the local women as objects of pleasure. Agary's rural setting depicts mostly female characters - girls, single mothers and abandoned wives whose lives have no prospects. With no specific name of the village, it represents a microcosm of the Niger Delta villages where female characters eke out a living amidst crude oil spills, badly polluted water ways with dead ecosystem. With no form of educational/developmental programs in place, young girls rarely engage in significant ventures. Rather, teen pregnancies produce many urchins which make the women "struggle for every meal" (77). The choice of the rural setting and Port Harcourt, an industrial oil rich city is not fortuitous as both places allow readers to grasp the effect of poverty and wealth put side by side "happy faces of people enjoying incredible opulence against the hardship suffered by the majority of the country" (122). Capitalist exploitation seemingly portrays the easy life in the city. Besides, the two settings suggest poverty amidst plenitude, it parodies the economic paradox of Nigeria, a rich nation with higher percentage of people wallowing in poverty. ${ }^{2}$

The beginning of the novel highlights the author' sconcerns and the biting effects of the degraded ecology on woman as Bibi gets covered with leaked crude oil while she works on her farm. Zilayefa's voice echoes her mother's quagmire as the dark spilled crude oil soaks her, impeding her agricultural work and forcing her out of her farm: I was at home one day when she returned shortly after leaving for the farm. When she got to the house, she knocked on the door and said very coldly 'Zilayefa, bring me bathing soap and sponge.' I was wondering why she needed them, I saw that her legs were stained black. What happened? .... 'Oil, Zilayefa' she said and turned away from me walking toward the river... 'Oil, from where?' I was walking behind her, and then I heard people shouting. A group of people painted in the same black as my mother, some covered from head to toe, was marching to see the Amananaowei, the head of the village. I joined them to find out what had happened. It turned out that some of them had also lost their farmland that day. They were marching to the Amananaowei's house to report the matter and demand that he take it up with the oil company. (YY 3-4: my emphasis)

It is important to note that women and nature are the primary victims of exploration that the ruling elites sustain to their advantage. Bibi's experience captures Cyril Obi's observation about how the over-exploited and thus "fragile ecosystem of the Niger Delta, directly threaten[ing] the livelihoods and futures of impoverished villagers" (174) especially the women as shown in the novel. Bibi's entanglement with spilled oil shows how in Yellow Yellow, ecofeminism links the suffering of the land to woman as the spilled crude oil (results of multinational oil companies' pressure on the environment of the Niger Delta) impedes Bibi's self-fulfillment and deters her farm's productivity. The black spilled oil on Bibi illustrates "how the domination of nature translates into the domination of other humans", the latter read as woman in this context (Elizabeth DeLoughrey and George B. Handley 16).

Bibi's response to the spilled oil becomes significant in accentuating the woes of subjugated woman and nature. Rather than follow the crowd to lodge complaints with Amananaowei, the local community leader, Bibi and her daughter head to the river pandering readers to the significance of ecology and woman's suffering. By choosing not to go to the community head, a male and collaborator with petroleum oil companies that exploit her environment, Bibi demonstrates her loss of confidence in the Nigerian/Niger Delta patriarchal leaders, accomplice of multinational oil companies whose joint efforts ruin woman and nature. Bibi's move towards the river evinces a connection between her and nature- she moves towards the river for purification, in order to rid herself of the entanglement produced by crude oil patriarchal capitalists. It is expected that washing in the river will bring up a cleaner and purified Bibi; cleansed from the black stain. But, her search for physical cleansing is complicated. Her purification is questionable and unattainable because the river from which she seeks purification is also degraded, and polluted due to mixture of spilled petroleum (9).Her suffering with nature makes it impossible for her to get away with the filth, an index of her entangled oppression. She and nature are inseparable victims about who Rose Ngomba-Roth condemns multinational oil companies' aggressive exploration of the Niger Delta crude oil (Ngomba-Roth 219). 
Thus Bibi is only left with purification in the metaphorical realm. She veers away from Amananaowei, the patriarchal oppressor. She returns to the river, Mother Nature, her partner in suffering - for metaphorical healing and cleansing.

Even within this rural setting, the ecofeminist implication of the positional inferiority of the Niger Delta woman becomes obvious. Bibi is no exception in the process of her repression by the patriarchy whose activities muted her voice. If Zilayefa wonders "what could have happened that left her (Bibi) void of words... when she was upset, she got very quiet" (3). Bibi's voiceless stance is metonymic as it shows a stark reality of unending frustration, abandonment, and powerlessness to which both the woman and the nature of Ijaw villages are subjected. Her lack of voice registers the subaltern position of traditional African woman that shows her to be inferior in the face of local and global exploiters represented by multinational oil companies and Niger Delta patriarchal capitalists - leaders e.g. Amananaowei and Admiral Amalayefa. - the sexagenarian retired military officer and a gigolo. Bibi's quietness reflects Gayatri Spivak's discourse about the subaltern position of woman that "[T]here is no space from which the sexed subaltern subject can speak" (Spivak103). It captures her hopelessness in getting out of the mess created by predators of 'women and nature' in theNiger Delta. The effect of present-day ecocide on Bibi and nature is in direct contrast to her maternal ancestors' experience whose precolonial roles suggest harmonious co-existence with nature prior to the fatal encounter with western multinational oil companies and their Nigerian accomplices who ruin the Niger Delta. Zilayefa laments:

Farming and fishing, the occupations that had sustained my mother, her mother and her mother's mother no longer provided gain. I had witnessed lands claimed by massive floods during the rainy season, the earth slowly melting into rivers. Women rowed their canoes farther and farther away to find land for farming. In addition, every year it was hard to catch fish... (40)

In this way contemporary Niger Delta woman groans under the burden of ecological degradation which consumes her, her environment and incapacitates her goal to self-fulfillment. The effect of the present ecocidal activities of the multinational oil companies and African patriarchal capitalist is biting when the narrator reminisces on the past. The novel unfolds the memory of the utopian past when nature flourished before the fossil exploitation. Then, "Ijaw women cooked a fresh pot of soup every day because the rivers were teeming with fish. Their farms held plantain trees so fertile that there was more plantain than anyone knew what to do with - ... the possibilities were endless" (40). In the olden days fertility of the land and rivers is juxtaposed with the woman's energy, flourishing and determination to succeed as a bread winner. It was a period when she would not only farm and fish to feed her family, she also ignored the nature of their men because she works towards self-sufficiency for her family (39-40). Then, her closeness to undefiled nature accentuates her sterling qualities as she teams with the Mother Nature to ensure continuity and productivity for both the healthy land and the people evident in production of abundant food.The peaceful symbiotic relationship between African woman and her land/rivers provides an impressive environment, a garden of Eden-like situation for people and nature.

\section{The Niger Delta woman and environment}

The intimacy and oneness between woman and nature manifests in Zilayefa's beauty and her mixed race identity. Rather than be addressed with her regular name, Zilayefa, is addressed in terms of her bi-racial color - Yellow Yellow. While mixed race people abound in the setting, Agary displays a strong ecofeminist propensity as Yellow Yellow places greater emphasis on bi-racial female characters. For example, Zilayefa, her receptionist colleague, Emem both about twenty years old, and the septuagenarian Madam George foreground how bi-racial coloration transcends generation in the novel. Their light skin identity is embedded in an ecofeminist ideals of the interconnections between woman and nature seen in Zilayefa's linkage with Mammy-water. On resumption of duty at a hotel in Port Harcourt, Zilayefa's supervisor, Moses acclaims in pidgin English "Dem don send us anodermami-wata o (71).InAfrican legends, Mammy Water evokes the proteiform of sharing European profile of light skin and long hair, however, her presence is overwhelming in the literary settings of riverine and coastal regions of Africa, the Caribbean islands, and Brazil. Her attributes of mermaid and africanriver goddess known as Yemoja among the Yoruba, Olokun among the Edo of Nigeria and Jengu in the Cameroun cannot be underestimated. She is invested with diverse imaginations in African literature. As a hybrid being, Mammy-Water unites the water, land andwoman (Ogunyemi 33, Nousi45) and assures Zilayefa a recognition at her beat - hotel reception desk. Zilayefa's incarnate of Mammy Water is seen in her attachment to water spirit - which she refers to often $(10,154,178)$. She avers: "I was used to being referred to as a mammy - water.... I was a follower of water's mother spirit...I had one of the qualifying characteristics- my complexion. Mammy-waters were said to be beautiful, light-skinned and possessed of wily charm" (71). In this wise, Zilayefa's physical features make her to be one and the same with (nature via) the river goddess. Her association with nature becomes further ingrained in her delicate andlight skin, black wavy hair which makes her stand out among crowd (19). 
She is beautiful just as mammy-water the water spirit is; she possesses the ability to procreate just as the pre-crude oil exploration of African rivers sustain productivity of sea animals. From the 1800 s to the present day crude-oil era (7375), Agary traces the origin of bi-racial mammy water children to their European fathers' entry by sea into African coast to ensnare local women. The European males' roles serve as a marker of sowing seeds of difference on African land.

\section{Patriarchal capitalists' subjugation of the Niger Delta woman and environment}

For rural Niger Delta female characters such as Bibi and much later her daughter, an encounter with European men complicates their frustration. If the environmental exploitation of oil companies worsens Bibi's life and spells doom for her farmland in the rural setting, she is not free from European capitalists' rape in Port Harcourt. Much younger, her search for a better life in the city sets her vulnerability in motion when she meets a Greek sailor who impregnates her with Zilayefa and abandons her. Mesmerized by the false love of this European, whose interest is a momentary sexual relief of many days at sea, Bibi falls into the hands of a mere Casanova and not a lover. Contrary to a fulfilling marital life which she looks forward to, Bibi in Zilayefa's words finds out that the Greek "was just gone, leaving his planted seed in my mother's belle." Sailors are mostly noted for carrying passengers/merchandise to and from their countries thus Zilayefa's Greek father, a sailor, portrays the capitalist West whose role is to explore the best out of Africa leaving behind his confusing 'deposits' (e.g. bi-racial children and toxic waste) ${ }^{4}$ on African land. That the indigene and victim of unplanned pregnancy under question is a woman is not by accident. It adumbrates the intersections between patriarchal capitalist rape of African woman and the ecological domination of her rivers emblematic of the sailor's ship. This Greek sailing on African rivers to dock on its shores evinces the colonizers' domination of Africa's waters ways. Beyond that, his entry into the Niger Delta via cruising and sailing on the river and his docking on the shore is another way of neocolonialist's 'penetration' of African land. First, the Greek's ship encroachment into African waters represents his phallus piercing into African's body to complete an ecological desecration of her nature/water and the rape of her Motherland seen in Bibi - the woman.

Ecofeminists' campaigns against being at odds with nature become flagrant as Bibi's body reeks with the shame of her embrace with the Greek sailor in Port Harcourt. He breaks into her body and desecrates it such as to re-echo the effect of imperialist/capitalist's rape that denies Africa of her wholesomeness. Second, Bibi's unsavory encounter with this sailor mimics the disappointment that attends to the Niger Delta peopleas soon as the exploration of crude oil follows its discovery. Rather than be a blissful encounter, it turns out to be a bitter one for the local people. Besides, Bibi's encounter with the Greek shatters her dreams, it signifies an end to her prospects of self fulfilment (7).She returns to nature in the rural setting where all her ambitions die only for her to hope in Zilayefa's future to which Bibi devoted a huge commitment (8-9). Bibi's return to the rural setting becomes further complicated. First she becomes a single mother, thus attracting a stigma that makes her to be pilloried within African societies that value marriage (NkansaObrepong 312). The stigma probably suggests why she remains unmarried hence she fights fervently to avoid her daughter falling into the same trap as she did with the Greek. Second, as an expectant mother with no support, Bibi becomes a sole bread-winner playing the double role of a father and mother to Zilayefa.

Bibi's past encounter with the Greek and her present with the oil spills reveal the destructive roles of patriarchal capitalists in their degradation of women and the environment. Bibi's body when she carries the Greek sailor's baby and much later as sticky crude oil covers her body allows for the reading of the simultaneous yoke, of the oppression that African woman and nature suffer at the hands of patriarchal capitalists - the sailor and activities of the crude oil explorers in the Niger Delta. Initially, ecofeminist hope resurfaces in Bibi who, rather than grieve over her condition of shame and oppression caused by the Greek sailor, determinedly makes recourse to land seen in her zeal to farm. Her impoverishment becomes a spring board for her to display resolution; she organises her life instead of agonizing over her plight. Her return to nature reminds readers of women in Angèle Kingue's Venus de Khalakanti (Nousi146) who, rejected and abandoned in the city, revert to land for sustenance. But Bibi's resilience to succeed portrays the endurance of Niger Delta woman who struggles under patriarchal yoke. Tilling the soil for a living brings her into close contact with nature suggesting an ecological interdependence between African woman and nature. Selling agricultural proceeds to finance her daughter's education, nature's economic provision sustains Bibi's efforts and replaces Zilayefa's absent father.

Bibi proudly hopes that: I [Zilayefa] would go to the university and study a subject that will get me a good job with enough to take care of myself, then I could take care of her. ... I knew that if I did not take care of her when I could finally take care of myself, the spirits of the water would tie my womb and make sure that, for my ungratefulness, I never experience the joy of motherhood. (10) 
Bibi's hopeslie in the expected symbiotic relationship between mother and daughter under the control of "the spirits of the water" - the umpire that oversees their relationship. It is significant that the spirits of the water, an ecofeminist agent, reverts to motherhood to reward or rebuke. Motherhood seen in the productive qualities of African women and nature is one of the moorings of ecofeminism (Green Ethics and Philosophy: An A-Z Guide: 139) and specifically Zilayefa identifies her as a female spirit who she "had to be careful not to offend [her] because female spirits unleashed the worst punishments when they were offended" (154). Hence, hope and determination to succeed come to the fore with the duo ofBibi and her daughter, under the watchful eyes of the water spirits. As Bibi ensures their survival through farming (nature), Zilayefa seeks education towards an improved future for the woman-kind. With nature as their bedrock, the duo constitute ecofeminist agents of hope.

Beyond Bibi's family, woman and nature face tortures as they wallow in a catastrophe of environmental degradation. Both are subjugated to battered, tattered, depleted environment that evokes misery, filth and death. Their misery is better captured by Tanure Ojaide who, in respect of Niger Delta people, illustrates that "[T]he health hazards are enormous and go unchecked, such as the methane and other chemicals that poison the people from the air they breathe, the land they farm and the water they drink" (Ojaidevi). More than the general populace, woman in particular bears the highest burden of the misery because mothers, allies of nature and of course Zilayefa, carry the brunt of the effect of ecological degradation as she laments:

My ears still rang from maternal wails piercing the foggy days when mothers mourned a child lost to sickness or to the deceptively calm waters that lay hungry below the stilt latrines waiting to swallow the children whose unsteady feet betrayed them before they had learnt to swim. How many more times could I bear the pain like razor blades slashing my private part because the river water that washed it was the same water that received the waste rejected by my body in an attempt to cleanse itself? The water that flowed with streaks of blue, purple and red, as drops of oil escaped from the pipelines that moved the wealth beneath my land and into the pockets of the select (sic) few who ruled Nigeria was the same water I drank. (39)

The uncertainties of the environment and the attendant death present unsavory entanglementfor woman and nature foreclosing a labyrinth of freedom. Thus, Zilayefa's village presents a repugnant and disorienting nature from where every young girl wants to escape by going to the cities to sell their bodies to rich men -the White and local capitalists. Proceeds of prostituting become a means through which the girls sustain their families back in the ecologically impoverished village (35). The girls' roles and hopes thus present a situational irony as they exiled their polluted village because of the white men's destruction of their land and rivers, only to offer their body to the same white men in the cities for further exploration and exploitation. In Yellow Yellow, girls and rural nature are thus perceived as victims, in terms of unending cycles of exploitation typical of ecofeminists' condemnation of the plight of women and nature in a degraded environment.

Faced with no means of survival in the overtly depleted rural setting, Zilayefa too manages to escape to Port Harcourt, not to engage in sex work, but in search of a brighter future from a diligently earned income. Sadly, just like Bibi, her daughter's encounter with the city ends up in sexual disorientation as she also goes through sexual exploitation from two city predators/capitalists - Sergio, a Spanish businessman, and Admiral. It turns out that Sergio is not only a sexual predator of Ijaw girls, but his roles demonstrate ecocide seen in the deforestation of the rural setting. He and his Ijaw friend Tarilabo "were interested in logging timber from the forests in our village and wanted to discuss that possibility with the Amananaowei" (22). It is significant to note that deforestation, another form of ecocide, is sustained by male characters -foreign and local demonstrated by Sergio, Tarilabo and Amananaowei. Agary's campaign against deforestation foregrounds men, local and global, as joint accomplices to the destruction of the Niger Delta land. These men pull down the products of the Mother Earth that ecofeminist female characters like Bibi's foremothers advocate for. Drawing from the reality of ecocide in the Niger Delta, these men's roles are the stark consequence of what activists like Ken SaroWiwa and Adaka Boro ${ }^{5}$ fought and died for in an unjust manner (34). Agary's condemnation of deforestation in the Niger Delta reverberates and resonates with that of NiyiOsundare in the way he condemns deforestation due to chaotic urbanization, modern civilization and technological advancement in The Eye of the Earth (Uwasomba 240). Beyond Osundare, Agary brings to fore the woes of ecofeminist's deploration of the degraded African woman, rivers and then the forests carried out by Tarilabo and Sergio.

In the village, Zilayefa's initial meeting with Sergio was under Bibi's watchful eyes which serve to restrain her from falling victim of Sergio's sexual prowess. Her closeness to natural environment and the protective stern warning from her mother, "Don't go and get carried away and spoil yourself o. My back is not ready for grandchildren" (23), kept her intact as Zilayefa refuses to let go of her wisdom in the village. Also, the stark reality of degraded rural environment and women's suffering in the setting empower Zilayefa against Sergio's advances. She escapes Sergio's despoliation in the village, but her land's timbers were not spared of his capitalist axe. 
Much later Zilayefa's embrace with the capitalist setting of Port Harcourt causes Admiral to deflower her (144) and later Sergio to have sex with her (172) only for both men to abandon her afterwards. Zilayefa gets pregnant but she dreads having a baby that will put her in the same line of failure as her mother. The repercussion of her own submission to the exploitation of city patriarchal capitalists causes her to regret her roles but Zilayefa breaks the chain of perpetuating capitalists' unwanted children typical of the setting. She resorts to abortion by vouching not to reproduce "more and more of my kind- 'African profits', 'born-throways', ashawo-pickins, ${ }^{6}$ father-unknowns, - running around the slums of Port Harcourt"(171). Her determination against contributing to fatherless babies is underscored as she manipulates the intimacy between her and nature; she uses certain fresh leaves to abort her pregnancy. In this situational irony, Zilayefa reverts to nature (leaves), a non-human victim of patriarchy, as a tool for removing the burden of patriarchal capitalists (the foetus) in order to rid herself of capitalists' subjugation. As a modern-day woman in the face of environmental/capitalist entanglement, Zilayefa demonstrates that the twenty-first century subaltern may not speak but she acts. Though in an environmental subjugation, Zilayefa shares the ideals of Toni Morisson's protagonist in The Beloved where raped female slaves resort to matricide to prevent giving birth to more slaves for capitalist slave masters.

That a woman manipulates nature to mitigate the negative effects of patriarchy deserves a closer study here. True, Zilayefa gets carried away by the allure of patriarchy in the city, but as a modern-day woman conscious of the implication of woman/nature degradation, she quickly retraces her steps away from capitalists' antics. Realizing her stray away from nature, she remorsefully "begged God for forgiveness, and called on my mother spirits for comfort" (178). Thus Zilayefa reconsiders matricide as a means of protest against misogynist, eco-unfriendly patriarchal capitalists. Because woman is well linked to land in ecofeminism, Zilayefa follows a fresh rebirth and orientation just like her fellow citizens become hopeful "jubilating over the death of the land's leader..." who died with two prostitutes (176) at the end of the story. Zilayefa's determination to turn a new leaf and follow the path of wisdom as laid down by Bibi is reflective of Nigeria's socio-political militancy after the military era.

\section{Conclusion}

Even though, the city thwarts the good path that Zilayefa has followed, her trajectory from the village to the city is laden with so much lures that make it difficult for her, in her late teen age years, not to fall into capitalist sexual predators' traps. Her predicament lays emphasis on the overwhelming degradation that capitalists subject African woman and nature to. She nonetheless symbolises her country which was about to re-consider her long path of bad governance seen in military regimes and instability. Zilayefa's unbridled freedom makes her offer her body to be used and dumped by the capitalists; her realisation of the insincerity of her multinational agent lovers suggests that she as a woman is equal to her country's environment. She is like her Nigerian land which capitalists only want to exploit, get the best out of, and abandon. Thus, Zilayefa's resolution to relieve herself of the pregnancy - the burden of the male oppressors can only be attained via her collaboration with nature, her fellow victim - in search of a true liberty, free from the yokes that oppress her and her land. Much as the novel lays emphasis on the entanglement between woman and the environment, Yellow Yellow is so rich in many untapped societal problems such as an enquiry into the elusive democracy in independent Africa, sexuality, the vagaries of modern African cityscape among others.

\section{Endnotes.}

${ }^{1}$.Ken SaroWiwa, an environmental activist of the Movement for the Survival of Ogoni People (MOSOP) was hanged by the Nigerian Military junta on November 10, 1995.SaroWiwa and eight other activists died for defending their people and land from environmental destruction caused by Oil Companies in the Niger Delta area of Nigeria. See TanellaBoni"The Polluting of the World and the Silence of African Writers". In Eco-Imagination: African and Diasporan Literatures and Sustainability. Ed IrèneAssibad'Almeida, Lucie Viakinnou-Brinson and Thelma Pinto. African World Press, 2014.

2. Nigeria is a rich country with mostly poor citizens. SeeMansour KhalidAfrica through the Eyes of a Patriot. A Tribute to General Olusegun Obasanjo. Routledge, 2013, p. 116.

3. Belle means belly in the Nigerian pidgin English spoken in the Niger Delta region of Nigeria.

4. In 1988, an Italian company dumped toxic waste at Koko, a coastal village in the Niger Delta. It caused pollution of the surface and underground water. Local evacuators have since suffered death, and critical health conditions. Another toxic waste was dumped in the same town in 2017. See "“Toxic waste in Koko." The Nation. 17 Mar. 2017 Editorial.

http://thenationonlineng.net/toxic-waste-koko/ Accessed 23 Aug. 2018.

5. “...G] [Ging down memory lane one is a bit saddened that the history of the Niger Delta struggle was started by another brave Izon son, Major Jasper Adaka Isaac Boro... He also paid the supreme price for a 12-day revolution ... and he was tried for treason and eventually released following the civil war after the first coup of 1966, was released and later died fighting to keep Nigeria One." See Willy Bozimo "Niger Delta: President Yar' Adua bares his fangs" in "The Nation" Friday, July 4, 2008 p. 15

${ }^{6}$. These are unwanted babies of whom their mothers are ashamed because of the circumstances surrounding their birth. Hence 'thrown away' just after birth are unwanted babies, products of prostitution/rape or from morally decadent women. 


\section{Works Cited}

Achebe, Chinua.Things Fall Apart. Heinemann, Pearson Education Limited 2008.

Africa through the Eyes of a Patriot. A Tribute to General Olusegun Obasanjo. Ed. Mansour Khalid Routledge, 2013.

Agary, Kaine. Yellow Yellow. Dtalkshop, 2006.

Awhefeada, Sunny. "Degraded Environment and Destabilized Women in KaineAgary'sYellow Yellow.'InEco-critical Literature: Regreening African Landscapes. Ed. OkuyadeOgaga.

African Heritage Press. 2013, pp. 95-108.

Boni,Tanella. "The Polluting of the World and the Silence of African Writers."In Eco-Imagination: Africanand Diasporan Literatures and Sustainability. Eds. IrèneAssibad'Almeida, Lucie Viakinnou-Brinson and Thelma Pinto. African World Press, New Jersey, 2014, pp 27-39.

Bozimo, Willy. "Niger Delta: President Yar' Adua bares his fangs" "The Nation” Friday, July 4, 2008.

Caminero-Santangelo,Byron."Different Shades of Green: Ecocriticism and African Literature"

In African Literature: An Anthology of Criticisms and Theory. Eds. TejumolaOlaniyan andAtoQuayson. Blackwell Publishing, 2007, pp. 698-706.

Chuma- Udeh,Ngozi. "The Niger Delta, Environment, Women and the Politics of Survival in KaineAgary'sYellow Yellow.'In Eco-critical Literature: RegreeningAfrican

Landscapes. Ed. OkuyadeOgaga. African Heritage Press. 2013, pp.109-122.

Crowley, D.Africa's Narrative Geographies: Charting the Intersections of Geocriticism. Palmgrave Macmillan, 2014.

Elizabeth DeLoughrey and HandleyGeorge B. Introduction "Toward an Aesthetics of the Earth" InPostcolonial Ecologies: Literatures of the Environment. Eds. Elizabeth DeLoughrey and George B. Handley. Oxford UP, 2011.

Green Ethics and Philosophy: An A-Z Guide. Eds. Julie Newman and Paul Robbins. SAGE, 2011.

Ngamba-Roth, Rose. Multinational Companies and Conflict in Africa:The Case of the Niger Delta. Verlag, 2007.

New Directions in Ecofeminist Literary Criticism. Ed. Andrea Campbell. Cambridge Scholars Publishing,2009.

Nkansa-Obrepong,James. Foundations of African Theological Ethics. Langham Monographs, 2013.

Nousi, Marie ChantaleMofin. "Eco-feminisme au cœur de la forêtafricaine: Venus de Khalakanti

d'AngèleKingue" In Eco-Imagination African and Diasporan Literatures and Sustainability. Eds. IrèneAssibad'Almeida, Lucie Viakinnou-Brinson and Thelma Pinto African World Press, 2014, pp 139-152.

Obi, Cyril I. "Global, state, and local intersections: power, authority, and conflict in the Niger Delta oil communities" In Interventions and Transnationalism in Africa: Global-Local

Networks of Power. Eds. Thomas Callaghy, Ronald Kassimir, Robert Latham. Cambridge University Press, 2001, pp. 173-194.

Ogunyemi,ChikwenyeOkonjo. Africa Wo/Man Palava. The Nigerian Novel by Women. The University ofChicago Press. 1996.

Ojaide,Tanure. "Foreword". InEco-critical Literature: Regreening African Landscapes. Ed. OkuyadeOgaga.African Heritage Press. 2013, pp. v-viii.

SalmanAneel and IqbalNuzhat. "Ecofeminist Movements - from the North to the South" The PakistanDevelopment Review. Vol. 46:4 Part II (Winter 2007) pp.853-864.

Senghor, Leopold Sedar. Chants d'ombre- Poésieschoisies. Rex Collins. 1976.

Shiva, Vandana. "Preface" in Ecofeminism. Eds. Vandana Shiva, and Maria Mies. Zed Books Ltd, 2014.

Slaymaker,William. "Echoing the Other(s): The Call of Global Green and Black African Responses" In African Literature: An Anthology of Criticisms and Theory. Eds. TejumolaOlaniyan and AtoQuayson. Blackwell Publishing, 2007, pp. 683-697.

SpivakGayatri, Chakravorty. "Can the Subaltern Speak?" In Colonial Discourse and Postcolonial Theory: A Reader. Eds. Patrick Williams and Laura Chrisman.Columbia U P, 1994. pp. 66-124.

Sturgeon,Noël.Ecofeminist Natures: Race, Gender, Feminist Theory and Political Action. Routledge, 2016.

"Toxic waste in Koko." The Nation. 17 Mar. 2017 Editorial. http://thenationonlineng.net/toxic- waste-koko/ Accessed 23 Aug. 2018.

Uwasomba, Chijioke. “'So that our earth shall not die": The Environmental Imagination of NiyiOsundare'sVillage Voices andThe Eye of the Earth." In Biotechnology Development and Threat of Climate Change in Africa: The Case of Nigeria. vol 2. Eds. Odunayo C. Adebooye, Kehinde A. Taiwo and Andrew A. Fatufe. CuvillierVerlag, 2010, pp. 234-249.

Warren, Karen J. "Taking Empirical Data Seriously: An Ecofeminist Philosophical Perspective" InEcofeminism, Women, Culture and Nature. Ed. Karen Warren. Indiana UP, 1997. 